\title{
LA PERSPECTIVA CIVIL DE LOS DERECHOS AL HONOR, LA INTIMIDAD Y LA PROPIA IMAGEN
}

\author{
Domingo Bello Janeiro \\ Catedrático de derecho civil de la Universidad de La Coruña \\ Email: domingo.bello@udc.es
}

RESUMEN: El derecho a la intimidad personal, en cuanto derivación de la dignidad de la persona (art. 10.1 de la Constitución Española, en adelante CE), implica la existencia de un ámbito propio y reservado frente a la acción y el conocimiento de los demás, necesario, según las pautas de nuestra cultura, para mantener una calidad mínima de la vida humana de forma que lo que el art. 18.1 CE garantiza es un derecho al secreto, a ser desconocido, a que los demás no sepan qué somos o lo que hacemos, vedando que terceros, sean particulares o poderes públicos, decidan cuales sean los lindes de nuestra vida privada, pudiendo cada persona reservarse un espacio resguardado de la curiosidad ajena, sea cual sea lo contenido en ese espacio de todo lo cual se deduce que el derecho a la intimidad confiere a la persona el poder jurídico de imponer a terceros el deber de abstenerse de toda intromisión en la esfera íntima y la prohibición de hacer uso de lo así conocido.

PALABRAS CLAVE: Honor, intimidad, propia imagen, libertad de expresión ABSTRACT: The right to personal privacy, as a derivation of the dignity of the person (Article 10.1 of the Spanish Constitution, hereinafter referred to as CE), implies the existence of an own and reserved space in front of the action and knowledge of the other, necessary, according to the guidelines of our culture, to maintain a minimum quality of human life so that what art. 18.1 CE guarantee is a right to secrecy, to be unknown, to others do not know what we are or what we do, prohibiting third parties, whether private individuals or public authorities, decide what are the boundaries of our private lives, each person can reserve a space sheltered from the curiosity of others, whatever is contained in that space from which it follows that the right to privacy gives the person the legal power to impose on third parties the duty to refrain from any interference in the intimate sphere and the prohibition of making use of the well-known.

KEY WORDS: Honor, intimacy, own image, freedom of speach 
En la concepción actual de persona nos referimos al ser humano, considerado tanto desde la perspectiva individual como desde la perspectiva jurídica, es decir, como sujeto de determinadas relaciones jurídicas que implican una serie de derechos y de obligaciones, y por lo tanto desde una doble perspectiva: la persona física, como ser individual, y, en su caso, la persona jurídica, en el marco de la colectividad o grupo que forma con otros seres humanos.

La Constitución Española de 29 de diciembre de 1978 se refiere a la persona en el artículo 10 cuando señala que "La dignidad de la persona, los derechos inviolables que le son inherentes, el libre desarrollo de la personalidad, el respeto a la ley y a los derechos de los demás, son el fundamento del orden político y de la paz social", precepto que, recogido entre el Título Preliminar y entre los derechos y deberes fundamentales, inspira el contenido de todos los derechos, y se enmarca en esa perspectiva de la persona considerada tanto en su aspecto individual como social, protegiendo su aptitud para ser titular de relaciones jurídicas, dentro de la idea genérica de la regulación de la vida social de la comunidad o de la paz social o pacificación de conflictos que se pretende alcanzar con el derecho.

En el Código Civil español el Libro Primero, que comprende los artículos 17 a 332 , lleva por rúbrica "De las personas", siguiendo el esquema de la Instituta de Gayo y el Código Civil francés, que son opuestos al que sigue la doctrina alemana en la que la persona se estudia en la parte general, como sujeto de derechos subjetivos.

Por derechos de la personalidad, se entienden desde esta perspectiva legal comúnmente aceptada los derechos que protegen los bienes de carácter estrictamente personal que se encuentran en la esfera de poder jurídico que tiene toda persona, y por tanto abarcan los que protegen sus manifestaciones físicas, como la vida o la integridad física, como también los de carácter moral, como el honor, la intimidad, o la imagen. Esos son los derechos subjetivos, o derechos de la personalidad, que se diferencian de los derechos de contenido patrimonial o de carácter social, por afectar a cualidades inherentes a la persona.

Sobre la naturaleza jurídica de estos derechos como derechos de la personalidad la Ley española de 26 de diciembre de 1978 de Protección Jurisdiccional de los Derechos Fundamentales de la Persona (modificada por RD de 20 de febrero de1979), se refiere a derechos fundamentales de la persona, aunque comprende también otros derechos que van más allá de los derechos de la personalidad.

Por su parte la Ley española Orgánica 1/82 de 5 de mayo de Protección Civil del Derecho al Honor, al Intimidad Personal y Familiar y a la Propia Imagen, en su preámbulo dice expresamente que "Los derechos garantizados por la Ley han sido encuadrados por la doctrina jurídica más autorizada entre los derechos de la personalidad (...)" y a su vez el Código Civil en el artículo 162 establece como exceptuados de la representación legal que los padres tienen sobre los hijos no emancipados "Los actos relativos a derechos de la personalidad (...)".

Estos derechos presentan, según la doctrina común, como caracteres básicos que son esenciales, porque toda persona los tiene por sí mismo, ya desde que nace hasta que 
muerte, (sin perjuicio de los matices sobre el comienzo de la personalidad), sin excepción alguna, y sin necesidad por consecuencia de reconocimiento expreso. Son absolutos, porque tienen poder inmediato y directo sobre el ámbito que protegen y son oponibles erga omnes.

Son indisponibles e imprescriptibles, porque no cabe la posibilidad por el titular de renunciar o disponer de ellos, ya que sería contraria a derecho por su carácter (artículo 6.2 del Código Civil español), salvo excepciones contadas (por ejemplo, la persona que dedicada al mundo del cine, la televisión o la publicidad, dispone de su imagen), y no prescriben porque están fuera del comercio de los hombres (artículo 1936 del Código Civil español).

Otros caracteres de los mismos son su carácter privado y su condición de extrapatrimonialidad, aunque en ocasiones su lesión pueda dar lugar a una indemnización cuantificable económicamente por el resarcimiento de los daños producidos.

Al respecto en el artículo 1.3 de la Ley española Orgánica 1/82 de 5 de mayo de Protección del Derecho al Honor, se señala que "El derecho al honor, la intimidad personal y familiar es irrenunciable, inalienable e imprescriptible" y continúa diciendo que "La renuncia a la protección prevista en esta Ley será nula sin perjuicio de los supuestos de autorización o consentimiento a que se refiere el artículo 2 de esta Ley, en el cual hace referencia a la protección del derecho al honor, intimidad y propia imagen como derecho delimitado por las leyes, y los usos sociales, (elemento interpretativo este último de gran importancia por la creciente comercialización de la vida privada justamente por los famosos), atendiendo al ámbito que cada persona mantenga reservado para si o para su familia, tras lo cual permite el consentimiento en dicho ámbito que dará lugar a que la intromisión no se considere ilegítima, y autoriza también la revocabilidad del consentimiento prestado.

La protección jurídica de estos derechos, es en primer lugar de carácter constitucional, y así existe una referencia general en el artículo 10.1 del Texto Constitucional español antes mencionado, y los artículos 14 y siguientes recogen los derechos que se reconocen concretamente.

Además, el desarrollo de estos derechos debe hacerse por ley que revista el carácter de ley orgánica (artículo 81.1), y se tutelan por un procedimiento preferente y sumario ante los Tribunales ordinarios y por el recurso de amparo ante el Tribunal Constitucional (artículo 53.2).

También se protegen estos derechos desde el punto de vista del derecho penal y el derecho administrativo, y así el Código Penal tipifica conductas que atentan contra derechos como la vida, el honor o la libertad, y en el Derecho Administrativo, existen normas en España que protegen el transplante de Órganos (Ley de 27 de octubre de 1979 y Reglamento de 22 de febrero de 1980), y la libertad religiosa (Ley de 5 de julio de 1980).

En el ámbito del derecho civil español se ha venido reconociendo desde una clásica sentencia de 6 de diciembre de 1912 la posibilidad de que se produzca una violación de estos derechos, reconociendo su protección y la consiguiente 
indemnización económica. Con posterioridad la sentencia del Tribunal Constitucional de 14 de julio de 1981 se pronunció sobre ellos señalando que "Son derechos subjetivos, derechos de los individuos no sólo en cuanto derechos de los ciudadanos en un sentido estricto, sino en cuanto garantiza un status jurídico o la libertad en un ámbito de la existencia; pero, al propio tiempo, son elementos esenciales de un ordenamiento objetivo de la comunidad nacional, en cuanto ésta se configura como marco de una convivencia humana justa y pacífica plasmada históricamente en el Estado de Derecho y, más tarde, en el Estado social de Derecho o el Estado social y democrático de Derecho, según la fórmula de nuestra Constitución (artículo 1.1)”.

Hoy en día al amparo del artículo 1902 del Código Civil español que regula la responsabilidad extracontractual es ya un hecho consumado la protección de los derechos de la personalidad ante los Tribunales.

Así las cosas, hay que puntualizar también que el capítulo Segundo del Título I de la Constitución Española lleva por rúbrica "Derechos y Libertades" y tras una proclamación de la igualdad contenida en el artículo 14, recoge derechos de contenido individual y colectivo en la Sección Primera (artículos 15 a 29) que lleva por rúbrica "De los derechos fundamentales y las libertades públicas".

Entre los de carácter individual se protegen los siguientes:

- El derecho a la vida en el artículo 15, que establece que: "Todos tienen derecho a la vida y a la integridad física y moral, sin que, en ningún caso, puedan ser sometidos a tortura ni a penas o tratos inhumanos o degradantes. Queda abolida la pena de muerte, salvo lo que puedan disponer las leyes penales militares para tiempos de guerra"

Como consecuencia de este derecho se protege la seguridad e higiene en el trabajo en el artículo 40.2; se reconoce el derecho a la protección de la salud y la obligación de los poderes públicos de tutelarla en el artículo 43; se establece también la obligación de los poderes públicos de velar por la utilización racional de todos los recursos del medio ambiente para proteger y mejorar la calidad de vida en el artículo 45.2; señalando al respecto el artículo 49 que los poderes públicos realizarán una política de previsión, tratamiento, rehabilitación e integración de los disminuidos físicos, sensoriales y psíquicos; mientras que por su parte el artículo 50 se refiere a la protección de la tercera edad garantizando su suficiencia económica mediante pensiones adecuadas, y el artículo 51 a la defensa de los consumidores y usuarios, entre cuyos objetivos está la protección de la salud.

- El derecho a la libertad personal, en el artículo 17, que dice textualmente que: "1. Toda persona tiene derecho a la libertad y a la seguridad. Nadie puede ser privado de su libertad, sino con la observancia de lo establecido en este artículo y en los casos y en la forma previstos en la ley. 2. La detención preventiva no podrá durar más del tiempo estrictamente necesario para la realización de las averiguaciones tendentes al esclarecimiento de los hechos, $\mathrm{y}$, en todo caso, en el plazo máximo de setenta y dos horas, el detenido deberá ser puesto en libertad o a disposición de la autoridad judicial. 3. Toda persona detenida debe ser informada de forma inmediata, y de modo que le sea comprensible, de sus derechos y de las razones de su detención, no pudiendo ser obligada a declarar. Se garantiza la asistencia de abogado al detenido en las diligencias policiales y judiciales, en los términos que la ley establezca. 4. La ley regulará un 
procedimiento de "habeas corpus" para producir la inmediata puesta a disposición judicial de toda persona detenida ilegalmente. Asimismo, por ley se determinará el plazo máximo de duración de la prisión provisional".

- El derecho al honor, a la intimidad personal y familiar y a la propia imagen, recogido en el artículo 18.1: "Se garantiza el derecho al honor, a la intimidad personal y familiar y a la propia imagen".

La inviolabilidad del domicilio, que establece el artículo 18. 2: "El domicilio es inviolable. Ninguna entrada o registro podrá hacerse en él sin consentimiento del titular o resolución judicial, salvo en caso de flagrante delito".

- La legalidad en materia penal o sancionadora recogida en el artículo 25.1: "Nadie puede ser condenado o sancionado por acciones u omisiones que en el momento de producirse no constituyan delito, falta o infracción administrativa, según la legislación vigente en aquel momento".

- La libertad de residencia y de circulación, a que se refiere el artículo 19: "Los españoles tienen derecho a elegir libremente su residencia y a circular por el territorio nacional. Asimismo, tienen derecho a entrar y salir libremente de España en los términos que la ley establezca. Este derecho no podrá ser limitado por motivos políticos o ideológicos".

Como derechos de carácter intelectual se protegen en la Constitución Española los siguientes:

- La libertad religiosa en el artículo 16: "1. Se garantiza la libertad ideológica, religiosa y de culto de los individuos y las comunidades sin más limitación, en sus manifestaciones, que la necesaria para el mantenimiento del orden público protegido por la ley. 2. Nadie podrá ser obligado a declarar sobre su ideología, religión o creencias. (...)".

- La inviolabilidad de las comunicaciones en el artículo 18.3: "Se garantiza el secreto de las comunicaciones y, en especial, de las postales, telegráficas y telefónicas, salvo resolución judicial".

- Las libertades de expresión y de información, en el artículo 20, que reconoce un conjunto de derechos relacionados con las mismas, y así textualmente señala: "1. Se reconocen y protegen los derechos: a) A expresar y difundir libremente los pensamientos, ideas y opiniones mediante la palabra, el escrito o cualquier otro medio de reproducción. b) A la producción y creación literaria, artística, científica y técnica. c) A la libertad de cátedra. d) A comunicar o recibir libremente información veraz por cualquier medio de difusión. La ley regulará el derecho a la cláusula de conciencia y al secreto profesional en el ejercicio de estas libertades. 2. El ejercicio de estos derechos no puede restringirse mediante ningún tipo de censura previa. 3. La ley regulará la organización y el control parlamentario de los medios de comunicación social dependientes del Estado o de cualquier ente público y garantizará el acceso a dichos medios de los grupos sociales y políticos significativos, respetando el pluralismo de la sociedad y de las diversas lenguas de España. 4. Estas libertades tienen su límite en el respeto a los derechos reconocidos en este Título, en los preceptos de las leyes que lo 
desarrollen y, especialmente, en el derecho al honor, a la intimidad, a la propia imagen y a la protección de la juventud y de la infancia. 5. Sólo podrá acordarse el secuestro de publicaciones, grabaciones y otros medios de información en virtud de resolución judicial".

- El derecho a la educación, en el artículo 27, que dice lo siguiente en sus párrafos 1 a 4: "1. Todos tienen el derecho a la educación. Se reconoce la libertad de enseñanza. 2. La educación tendrá por objeto el pleno desarrollo de la personalidad humana en el respeto a los principios democráticos de convivencia y a los derechos y libertades fundamentales. 3. Los poderes públicos garantizan el derecho que asiste a los padres para que sus hijos reciban la formación religiosa y moral que esté de acuerdo con sus propias convicciones. 4. La enseñanza básica es obligatoria y gratuita”.

Por último, por lo que se refiere al marco legal constitucional que estamos reproduciendo, como libertades colectivas, la Constitución Española protege las siguientes:

- La libertad de partidos políticos, en el artículo 6: "Los partidos políticos expresan el pluralismo político, concurren a la formación y manifestación de la voluntad popular y son instrumento fundamental para la participación política. Su creación y el ejercicio de su actividad son libres dentro del respeto a la Constitución y a la ley. Su estructura interna y funcionamiento deberán ser democráticos".

- La libertad de reunión y manifestación en el artículo 21: “1. Se reconoce el derecho de reunión pacífica y sin armas. El ejercicio de este derecho no necesitará autorización previa. 2. En los casos de reuniones en lugares de tránsito público y manifestaciones se dará comunicación previa a la autoridad, que sólo podrá prohibirlas cuando existan razones fundadas de alteración del orden público, con peligro para personas o bienes".

- La libertad de asociación, en el artículo 22: "1. Se reconoce el derecho de asociación. 2. Las asociaciones que persigan fines o utilicen medios tipificados como delito son ilegales. 3. Las asociaciones constituidas al amparo de este artículo deberán inscribirse en un registro a los solos efectos de publicidad. 4. Las asociaciones sólo podrán ser disueltas o suspendidas en sus actividades en virtud de resolución judicial motivada. 5. Se prohíben las asociaciones secretas y las de carácter paramilitar".

- Los derechos de sindicación y de huelga, en el artículo 28: "1. Todos tienen derecho a sindicarse libremente. La ley podrá limitar o exceptuar el ejercicio de este derecho a las Fuerzas o Institutos armados o a los demás Cuerpos sometidos a disciplina militar y regulará las peculiaridades de su ejercicio para los funcionarios públicos. La libertad sindical comprende el derecho a fundar sindicatos y a afiliarse al de su elección, así como el derecho de los sindicatos a formar confederaciones y a fundar organizaciones sindicales internacionales o afiliarse a las mismas. Nadie podrá ser obligado a afiliarse a un sindicato. 2. Se reconoce el derecho a la huelga de los trabajadores para la defensa de sus intereses. La ley que regule el ejercicio de este derecho establecerá las garantías precisas para asegurar el mantenimiento de los servicios esenciales de la comunidad". 
Así las cosas, ya en el mismo año 1981 de funcionamiento del Tribunal Constitucional en España, la libertad de información, y la de expresión, son objeto de un recurso de amparo ante el Tribunal Constitucional formulado por varios periodistas de los diarios La Voz de España y Unidad de San Sebastián después de que la Audiencia Nacional y el Tribunal Supremo fallaran en su contra y en favor de la decisión del Consejo de Dirección del Organismo Autónomo Medios de Comunicación Social del Estado de suspender la publicación de los citados diarios.

Las argumentaciones de los periodistas recurrentes son que la supresión de los dos diarios les priva del ejercicio de la libertad de expresión a los periodistas de su plantilla y lesiona los derechos y libertades del artículo 20 (apartados 1, a y d y apartado 2). b) y que acuerdo recurrido vulnera el apartado 3 del mismo artículo que ordena que ha de hacerse por ley la organización y control parlamentario de los medios de comunicación social dependientes del Estado.

Dejando al margen cuestiones como si el acto administrativo fue correcto o no y si hubo indefensión de los recurrentes, cuestiones que no plantearon los periodistas afectados y que el Tribunal decide no enjuiciar, el tema esencial es la anulación del acto por vulneración de la libertad de expresión.

El Tribunal Constitucional español en esta primera sentencia de 16 de marzo de 1981 recuerda que el artículo 20 garantiza el mantenimiento de una comunicación pública libre, sin la cual quedarían vaciados de contenido real otros derechos que la Constitución consagra, reducidas a formas nuevas las instituciones representativas y absolutamente falseado el principio de legitimidad democrática que enuncia el artículo 1 apartado 2 de la Constitución y que es la base de nuestra ordenación jurídico-políticas.

Y el Tribunal Constitucional en esta primeriza sentencia refuerza después su declaración de que no hay sociedad libre ni soberanía popular sin comunicación libre, de la que gozan todos los ciudadanos sin ingerencia de los poderes públicos y de la propia ley que vaya mas allá de los límites que fija la Constitución (20.4 y 53.1).

El derecho a comunicar y recibir información veraz incluye dos derechos distintos, pero íntimamente conectados. El derecho a comunicar, es decir: la libertad de expresión; y el derecho a recibir, justificada su inclusión en el texto constitucional, por el propósito de ampliar al máximo el conjunto de los legitimados para impugnar cualquier perturbación de la libre comunicación social.

El Tribunal Constitucional, en la sentencia que venimos reproduciendo de 16 de marzo de 1981 dice que estos derechos son comunes a todos los ciudadanos y frente al poder público, pero no se derivan de ellos ningún privilegio y desde luego no el de transformar en su favor (de los periodistas concurrentes) lo que para el común de los ciudadanos es derecho de libertad en un derecho de prestación que les legitima para exigir de los poderes públicos la creación o el mantenimiento de medios de comunicación a través de los cuales puedan expresar sus opiniones o comunicar información».

Y añade el Tribunal como actores destacados con el proceso de la libre comunicación social, los profesionales de la comunicación pueden invocar derechos cuya configuración concreta es mandato que la Constitución (artículo 20.1, d), in fine) 
da al legislador, pero no se han invocado esos derechos en el presente recurso, ni sirven los mismos para asegurar la permanencia de la actividad profesional, sino sólo el modo de su ejercicio.

La argumentación primera, es rechazada por el Tribunal Constitucional ya que el recurso se plantea no invocando los derechos del artículo 20 (apartado 1 a) y d y apartado 2) sino al modo de su ejercicio, porque no cabe de estas obligaciones, el derecho a exigir el apoyo con fondos públicos a determinados medios privados de comunicación social o la creación o el sostenimiento de un determinado medio del mismo género y de carácter público.

A continuación el Tribunal Constitucional afirma que el Organismo Autónomo Medios de Comunicación Social del Estado tenía faculta- des por razones económicas, o de otro género, para adoptar las medidas de sus- pensión, transformación o ampliación que fueran conducentes a la mayor efica- cia del servicio que hayan de administrar, de acuerdo con la habilitación que se confirió al Gobierno por el Real Decreto Ley 231/1977, de 1 de abril y que está previsto en la Ley de 26 de diciembre de 1958, artículo 2 .

El Magistrado señor Fernández Viagas formula voto particular a la sentencia que hemos reproducido de 16 de marzo de 1981 discrepando de su fallo; al rechazar la afirmación de que los periodistas no han comparecido en el recurso para invocar derechos específicos de su profesión, tras lo cual señala que el destino de los medios de comunicación fue estudiado por el Programa de actuación jurídica y política, Pactos de la Moncloa, aprobado el 27 de octubre de 1977, en cuyo epígrafe 2, del apartado 6111 , dice que una subcomisión de cultura del Congreso propondría al Gobierno un tratamiento de los medios de comunicación, subcomisión que se constituyó el 25 de enero de 1978, y que el Congreso y el Senado, por resoluciones de 27 de octubre y 11 de noviembre de 1977 asumieron la responsabilidad que les incumbía de control y funcionamiento de estos medios, habiendo el Gobierno incumplido este control y no puede sustraerse a este conuol la suspensión indefinida de unos medios que tampoco parece asumida en la ley ordinaria, por lo que su supresión puede considerarse contraria a la libertad de expresión.

Después de esta primera sentencia sobre la intimidad ha recaído una muy nutrida jurisprudencia constitucional en España de la que puede ser un buen ejemplo la STC 173/2011, de 7 de noviembre de 2011 tanto por el tema controvertido cuanto por las numerosas referencias jurisprudenciales que contiene.

El caso de que trata esta sentencia del Tribunal Constitucional fue resuelto por la Sentencia de la Audiencia Provincial de Sevilla que condenó al recurrente como autor de un delito de corrupción de menores del art. 189.1 b) del Código penal a la pena de cuatro años de prisión e inhabilitación especial para el derecho de sufragio pasivo durante el tiempo de la condena, siendo los hechos probados que "Entre los meses de noviembre y diciembre de 2007, el acusado (mayor de edad y sin antecedentes penales) ha tenido en su ordenador personal portátil numerosos ficheros de fotografías y videos mostrando a menores de edad - muchos de los cuales no alcanzan los trece añossolos o acompañados de otros menores, desnudos en actitudes y prácticas explícitamente sexuales." 
Así, en la carpeta "Mis documentos/mis imágenes" el acusado conservaba 17 videos y más de 3.000 fotografías de contenido pedófilo, y en la carpeta "eMule/Incoming" almacenaba más de 140 vídeos y más de 150 fotografías de pornografía infantil.

Los ficheros que representaban tales imágenes fueron obtenidos por el acusado, mediante el sistema de intercambio de archivos en Internet conocido como peer to peer, utilizando el mencionado programa eMule, por el que se comparten imágenes mediante su descarga y distribución simultánea. Por este sistema, el acusado -que tenía configurado el programa eMule para poner a disposición de cualquier otro usuario de la red todos los archivos contenidos en el disco duro de su ordenador- distribuyó material pornográfico de menores (muchos de ellos, menores de trece años) en una cantidad equivalente a unos 96 gigabytes.

Frente a la alegada lesión del derecho a la intimidad, planteada por el recurrente como cuestión previa, la Audiencia Provincial de Sevilla responde que "Las presentes actuaciones dimanan de la denuncia formulada por el testigo [...] Según la misma (fs. 15-16) — coincidente con su declaración en el plenario-, el acusado se personó en su establecimiento (APP Informática) entregándole su ordenador portátil con el encargo de cambiar la grabadora, que no funcionaba. Una vez efectuada la reparación y para comprobar el correcto funcionamiento de las piezas sustituidas, el testigo - como al parecer es práctica habitual- escogió al azar diversos archivos de gran tamaño (fotografías, videos o música) para grabarlos y reproducirlos en el ordenador, visualizándose entonces las imágenes pornográficas que contenía. El testigo puso entonces tal circunstancia en conocimiento de la Policía Nacional, que procedió a la intervención del portátil y al examen de su contenido, sin solicitar autorización judicial al efecto.

Pues bien, el Tribunal no considera que la actuación de la Policía Nacional vulnerara el derecho a la intimidad del inculpado atendiendo a dos razones:

1. El testigo especificó en juicio que, al recibir el encargo, preguntó al acusado si el ordenador tenía contraseña, a lo que el cliente le respondió que no, sin establecerle limitación alguna en el uso del ordenador y acceso a los ficheros que almacenaba.

En consecuencia, pese a conocer que el técnico accedería al disco duro del ordenador (pues para ello le solicitó la contraseña), el acusado consintió en ello sin objetar nada ni realizar ninguna otra prevención o reserva que permita concluir que pretendía mantener al margen del conocimiento ajeno determinada información, datos o archivos.

2. En ello abunda precisamente el hecho de que, como señaló el perito funcionario policial núm. 101.182 corroborando así la conclusión del informe pericial documentado (f. 120), el acusado tenía configurado el programa eMule de manera que todos los archivos del disco estuvieran a disposición de cualquier otro usuario de la aplicación.

En definitiva, se considera que difícilmente puede invocarse el derecho a la intimidad cuando los propios actos del acusado indican paladinamente que no tenía intención ni voluntad alguna de preservar para su esfera íntima, exclusiva y personal 
ninguno de los ficheros que conservaba en su ordenador, pues a ellos tenía acceso cualquier persona que se conectara en Internet a la misma red de intercambio."

Frente a dicha sentencia de la Audiencia, la posterior Sentencia del Tribunal Supremo desestimó el recurso de casación interpuesto. Respecto del motivo que denunciaba la vulneración del derecho a la intimidad, responde la Sala Segunda en los siguientes términos:

"Mas lo ocurrido es que sí existió la autorización... En efecto, declara, hasta en el juicio oral, el dueño del establecimiento, acompañando una hoja de trabajo que dice 'cambiar grabadora DVD-no lee muchos DVD', que el acusado le llevó el ordenador portátil para que se lo reparara, porque funcionaba mal la grabadora, y no le puso límite alguno para entrar en el ordenador; uno de los técnicos procedió al cambio de la grabadora y se trató de probar, como es habitual, el correcto funcionamiento de las piezas, para lo que el técnico fue a la carpeta de 'mis documentos/mis imágenes' y, de repente, se pudo ver en miniatura lo que parecían fotografías de pornografía infantil..., no fue necesario el empleo de contraseña alguna y le había dicho que no la había; y llevó el ordenador a la Policía... Es decir, no hubo injerencia inconsentida para disponer de un elemento de prueba, sino la voluntaria puesta por el afectado, de ese elemento, a disposición de un número abierto de receptores.

Pero es más, el informe policial establece que el ordenador tenía instalado el programa eMule de intercambio de ficheros tipo peer to peer; con el cual programa se accede a los contenidos que tienen compartidos todos los equipos conectados a Internet que estén utilizando eMule y, a su vez, se comparten las carpetas que se determinen del equipo propio; en la carpeta de descarga por defecto llamada "Incoming" se almacenan los ficheros descargados; se pueden determinar las carpetas a compartir con los demás usuarios, pero hay algo común a todos, la carpeta de descarga siempre es compartida; en el contenido de la carpeta de descarga y compartida "Incoming" se encontraban los archivos con las imágenes a que afecta este proceso.

Con todo ello se concluye la existencia de dos factores interconectados: a) el acusado no había dispuesto un ámbito de privacidad respecto al contenido pornográfico infantil del ordenador; b) no fue necesaria, en el presente caso, gestión alguna para desvelar la identidad del condenado, como usuario del ordenador y de su contenido. 3. La demanda de amparo se fundamenta en la vulneración del derecho a la intimidad (art. 18.1 CE) y de los derechos a un proceso con todas las garantías y a la presunción de inocencia (art. 24.2 CE). Considera el recurrente vulnerado su derecho a la intimidad porque tanto el dueño de la tienda donde llevó a reparar el ordenador como los policías nacionales que accedieron al ordenador actuaron sin previa autorización judicial. Alega que la policía al recibir la denuncia debía haber solicitado autorización del Juez. Por otra parte, tampoco existían motivos de urgencia que legitimaran una actuación policial inmediata. De igual modo que, tanto para acceder al contenido de la correspondencia salvo las que incorporan una declaración de contenido-, como para acceder a los registros de llamadas de un teléfono móvil es necesaria autorización judicial que debe exigirse para acceder al contenido de un ordenador personal. Además, discrepa asimismo de la argumentación de los órganos judiciales pues no cabe afirmar un consentimiento siquiera tácito a la divulgación de la información contenida en el ordenador. Por más que hubiera manifestado que carecía de contraseña, el ordenador fue entregado en la tienda únicamente para la reparación de la grabadora y no para el acceso 
a los documentos. Y tampoco puede justificarse tal consentimiento en el hecho de que compartía los archivos a través del programa eMule, pues ese dato sólo se obtiene a posteriori una vez que ya se ha accedido al contenido del equipo.

En segundo lugar entiende vulnerado el derecho a un proceso con todas las garantías (art. 24.2 CE), por haberse utilizado prueba ilícita para fundar la condena dada la lesión del derecho a la intimidad; además, la totalidad de las pruebas en que se basa la condena se derivan directa o indirectamente del hallazgo de los archivos obtenido con vulneración del art. 18.1 CE, por lo que resulta lesionado también el derecho a la presunción de inocencia (art. 24.2 CE). Especifica al respecto que tampoco puede servir a tal fin la declaración del propio recurrente, puesto que en el acto del juicio oral se acogió a su derecho a no declarar y la acusación no solicitó la lectura de sus declaraciones prestadas ante el Juez de instrucción.

Así las cosas, el Ministerio Fiscal, en escrito registrado el 24 de noviembre de 2010, interesó el otorgamiento del amparo por vulneración del derecho a la intimidad (art. 18.1 CE) y del derecho a un proceso con todas las garantías (art. 24.2 CE).

Después de exponer la doctrina constitucional sobre el derecho a la intimidad, manifiesta que el ordenador es un elemento idóneo para albergar datos personales contenidos en los archivos informáticos $\mathrm{y}$, con ello, para ejercer el derecho a la intimidad, por lo que para su acceso resulta preciso el consentimiento del titular o, en su caso, la existencia de razones de necesidad y urgencia y un juicio positivo de proporcionalidad. Respecto al acceso del encargado de la tienda a la carpeta "mis documentos", discrepa el Ministerio público de los argumentos esgrimidos por las resoluciones judiciales recurridas, pues considera que ni hubo un consentimiento expreso por parte del demandante de amparo, ni cabe afirmar la realización de actos concluyentes e inequívocos de los que quepa inferir un consentimiento tácito. Por ello, el acceso a los archivos del ordenador por parte del encargado de la tienda vulneró el derecho a la intimidad.

En relación a la actuación de la policía judicial, asevera el Ministerio Fiscal, tras citar lo que se afirma en la STC 70/2002, de 25 de abril, que una vez entregado el ordenador junto con la formulación de la denuncia, la policía habría podido solicitar el consentimiento del recurrente, quien se hallaba ya identificado, o bien haber recabado autorización judicial. En ausencia de tales requisitos habilitantes, el acceso al contenido del ordenador únicamente podría considerarse legítimo cuando existiesen razones de necesidad de una intervención policial inmediata para la prevención y averiguación del delito, el descubrimiento del delincuente y la obtención de pruebas incriminatorias, y sólo cuando la intervención se realizara desde el respeto al principio de proporcionalidad; circunstancias de urgencia y necesidad que no concurren en el caso concreto.

Por otra parte, no cabe justificar la actuación policial con el argumento de que el denunciante ya había accedido a los mismos, ni tampoco en que el recurrente tuviera configurado un programa de intercambio de archivos con acceso a terceros. En relación con esta última circunstancia, asevera el Ministerio público que ese hecho no permite abrigar una suerte de autorización genérica para el acceso por cualesquiera personas al contenido de su ordenador, debiendo tenerse en cuenta, asimismo, que el conocimiento 
de la existencia del programa informático de intercambio de archivos se obtiene sólo una vez se ha accedido al ordenador.

A continuación, se plantea el Ministerio Fiscal si la vulneración del derecho a la intimidad (art. 18.1 CE) conllevaría, además, la lesión del derecho a un proceso con todas las garantías (art. 24.2 CE), por haberse valorado prueba obtenida con vulneración de derechos fundamentales. Las pruebas practicadas en el juicio oral y valoradas por los órganos judiciales han sido, además del hallazgo de los archivos pedófilos, el testimonio del testigo dueño de la tienda de informática y el del policía instructor del atestado, quien además depuso como perito del informe pericial que se aportó como prueba documental pericial. El hallazgo de los archivos proviene directamente de la medida lesiva del derecho fundamental, pero para determinar si las restantes pruebas derivadas adquieren también ese carácter, es preciso analizar si son jurídicamente independientes (STC 81/1998, de 2 de abril). Por lo que respecta a la testifical del policía, considera el Fiscal que es materialmente inescindible de la prueba originaria, por no ser sino mera reproducción vía testimonio del acto de injerencia en el derecho fundamental; a igual conclusión llega respecto de la prueba pericial, hallándose también en conexión de antijuridicidad con el hallazgo ilícito de los archivos pedófilos. Distinta suerte ha de correr, no obstante, la prueba testifical del encargado del establecimiento, atendiendo a la menor entidad de la lesión del derecho a la intimidad — al no ser intencional— del que tal prueba proviene.

Pudiendo considerarse lícita la citada declaración testifical del encargado de la tienda, y habiéndose valorado conjuntamente con otras que sí deben ser consideradas ilícitas y deben, por ello, ser expulsadas del ordenamiento, concluye el Ministerio Fiscal que desde las competencias atribuidas al Tribunal Constitucional no puede éste efectuar un pronunciamiento sobre la entidad probatoria de dicha prueba a los efectos de su relevancia para la presunción de inocencia, por lo que lo procedente sería declarar la vulneración del derecho a la intimidad (art. 18.1 CE) y el derecho a un proceso con todas las garantías (art. 24.2 CE); anular las resoluciones recurridas y retrotraer el procedimiento al momento anterior a dictarse la Sentencia de la Audiencia Provincial, para que sean los órganos judiciales quienes valoren la suficiencia de la prueba carente del vicio de ilicitud.

Pues bien, sobre ello el Tribunal Constitucional de España en esta sentencia de 7 de noviembre de 2011 dice que para dar respuesta a la cuestión nuclear que se plantea en la demanda es preciso, en primer lugar, exponer la doctrina que este Tribunal ha desarrollado en relación con el derecho fundamental a la intimidad (art. 18.1 CE).

Sobre ello recuerda que el derecho a la intimidad personal, en cuanto derivación de la dignidad de la persona (art. 10.1 CE), implica la existencia de un ámbito propio y reservado frente a la acción y el conocimiento de los demás, necesario, según las pautas de nuestra cultura, para mantener una calidad mínima de la vida humana (SSTC 207/1996, de 16 de diciembre, FJ 3; 186/2000, de 10 de julio, FJ 5; 196/2004, de 15 de noviembre, FJ 2; 206/2007, de 24 de septiembre, FJ 4; y 159/2009, de 29 de junio, FJ 3). De forma que "lo que el art. 18.1 garantiza es un derecho al secreto, a ser desconocido, a que los demás no sepan qué somos o lo que hacemos, vedando que terceros, sean particulares o poderes públicos, decidan cuales sean los lindes de nuestra vida privada, pudiendo cada persona reservarse un espacio resguardado de la curiosidad ajena, sea cual sea lo contenido en ese espacio" (SSTC 127/2003, de 30 de junio, FJ 7 y 
89/2006, de 27 de marzo, FJ 5). Del precepto constitucional citado se deduce que el derecho a la intimidad confiere a la persona el poder jurídico de imponer a terceros el deber de abstenerse de toda intromisión en la esfera íntima y la prohibición de hacer uso de lo así conocido (SSTC 196/2004, de 15 de noviembre, FJ 2; 206/2007, de 24 de septiembre, FJ 5; y 70/2009, de 23 de marzo, FJ 2).

No obstante lo anterior, añade que el propio Tribunal Constitucional español ha venido precisando que el consentimiento eficaz del sujeto particular permitirá la inmisión en su derecho a la intimidad, pues corresponde a cada persona acotar el ámbito de intimidad personal y familiar que reserva al conocimiento ajeno (SSTC 83/2002, de 22 de abril, FJ 5 y 196/2006, de 3 de julio, FJ 5), aunque este consentimiento puede ser revocado en cualquier momento (STC 159/2009, de 29 de junio, FJ 3). Ahora bien, se vulnerará el derecho a la intimidad personal cuando la penetración en el ámbito propio y reservado del sujeto "aun autorizada, subvierta los términos y el alcance para el que se otorgó el consentimiento, quebrando la conexión entre la información personal que se recaba y el objetivo tolerado para el que fue recogida" (SSTC 196/2004, de 15 de noviembre, FJ 2; 206/2007, de 24 de septiembre, FJ 5; y 70/2009, de 23 de marzo, FJ 2). En lo relativo a la forma de prestación del consentimiento, hemos manifestado que éste no precisa ser expreso, admitiéndose también un consentimiento tácito. Así, en la STC 196/2004, de 15 de noviembre, en que se analizaba si un reconocimiento médico realizado a un trabajador había afectado a su intimidad personal, reconocimos no sólo la eficacia del consentimiento prestado verbalmente, sino además la del derivado de la realización de actos concluyentes que expresen dicha voluntad (FJ 9). También llegamos a esta conclusión en las SSTC 22/1984, de 17 de febrero, y 209/2007, de 24 de septiembre, en supuestos referentes al derecho a la inviolabilidad del domicilio del art. 18.2 CE, manifestando en la primera que este consentimiento no necesita ser "expreso" (FJ 3) y en la segunda que, salvo casos excepcionales, la mera falta de oposición a la intromisión domiciliar no podrá entenderse como un consentimiento tácito (FJ 5).

Por otra parte, se añade por parte del Tribunal Constitucional en esta STC 173/2011, de 7 de noviembre de 2011 que tampoco podrá considerarse ilegítima aquella injerencia o intromisión en el derecho a la intimidad que encuentra su fundamento en la necesidad de preservar el ámbito de protección de otros derechos fundamentales u otros bienes jurídicos constitucionalmente protegidos (STC 159/2009, de 29 de junio, FJ 3). A esto se refiere la doctrina del Tribunal Constitucional cuando alude al carácter no ilimitado o absoluto de los derechos fundamentales, de forma que el derecho a la intimidad personal, como cualquier otro derecho, puede verse sometido a restricciones (SSTC 98/2000, de 10 de abril, FJ 5; 156/2001, de 2 de julio, FJ 4; y 70/2009, de 23 de marzo, FJ 3). Así, aunque el art. 18.1 CE no prevé expresamente la posibilidad de un sacrificio legítimo del derecho a la intimidad - a diferencia de lo que ocurre en otros supuestos, como respecto de los derechos reconocidos en los arts. 18.2 y $3 \mathrm{CE}-$, su ámbito de protección puede ceder en aquellos casos en los que se constata la existencia de un interés constitucionalmente prevalente al interés de la persona en mantener la privacidad de determinada información. Precisando esta doctrina, recordábamos en la STC 70/2002, de 3 de abril, FJ 10 (resumiendo lo dicho en la STC 207/1996, de 16 de diciembre, FJ 4) que los requisitos que proporcionan una justificación constitucional objetiva y razonable a la injerencia en el derecho a la intimidad son los siguientes: la existencia de un fin constitucionalmente legítimo; que la medida limitativa del derecho esté prevista en la ley (principio de legalidad); que como regla general se acuerde mediante una resolución judicial motivada (si bien reconociendo que debido a la falta de 
reserva constitucional a favor del Juez, la ley puede autorizar a la policía judicial para la práctica de inspecciones, reconocimientos e incluso de intervenciones corporales leves, siempre y cuando se respeten los principios de proporcionalidad y razonabilidad) y, finalmente, la estricta observancia del principio de proporcionalidad, concretado, a su vez, en las tres siguientes condiciones: "si tal medida es susceptible de conseguir el objetivo propuesto (juicio de idoneidad); si, además, es necesaria, en el sentido de que no exista otra medida más moderada para la consecución de tal propósito con igual eficacia (juicio de necesidad); y, finalmente, si la misma es ponderada o equilibrada, por derivarse de ella más beneficios o ventajas para el interés general que perjuicios sobre otros bienes o valores en conflicto (juicio de proporcionalidad en sentido estricto)" (STC 89/2006, de 27 de marzo, FJ 3).

Por lo que se refiere a la concurrencia de un fin constitucionalmente legítimo que puede permitir la injerencia en el derecho a la intimidad, esta sentencia de 7 de noviembre de 2011 recuerda que el Tribunal Constitucional ha venido sosteniendo que reviste esta naturaleza "el interés público propio de la investigación de un delito, y, más en concreto, la determinación de hechos relevantes para el proceso penal" (SSTC 25/2005, de 14 de febrero, FJ 6 y 206/2007, de 24 de septiembre, FJ 6). En efecto, "la persecución y castigo del delito constituye un bien digno de protección constitucional, a través del cual se defienden otros como la paz social y la seguridad ciudadana, bienes igualmente reconocidos en los arts. 10.1 y 104.1 CE" [SSTC 127/2000, de 16 de mayo, FJ 3 a) y 292/2000, de 30 de noviembre, FJ 9]. También hemos precisado que "reviste relevancia e interés público la información sobre los resultados positivos o negativos que alcanzan en sus investigaciones las fuerzas y cuerpos de seguridad, especialmente si los delitos cometidos entrañan una cierta gravedad o han causado un impacto considerable en la opinión pública, extendiéndose aquella relevancia o interés a cuantos datos o hechos novedosos puedan ir descubriéndose por las más diversas vías, en el curso de las investigaciones dirigidas al esclarecimiento de su autoría, causas y circunstancias del hecho delictivo" (STC 14/2003, de 28 de enero, FJ 11).

De lo anterior, se deduce en esta STC 173/2011, de 7 de noviembre de 2011que el legislador ha de habilitar las potestades o instrumentos jurídicos que sean adecuados para que, dentro del respeto debido a los principios y valores constitucionales, las fuerzas y cuerpos de seguridad del Estado cumplan con esta función de averiguación del delito. Como se reseña en la STC 70/2002, de 3 de abril, FJ 10, "[p]or lo que respecta a la habilitación legal en virtud de la cual la policía judicial puede practicar la injerencia en el derecho a la intimidad del detenido, en el momento de la detención, las normas aplicables son, en primer lugar el art. 282 LECrim, que establece como obligaciones de la policía judicial la de 'averiguar los delitos públicos que se cometieron en su territorio o demarcación; practicar, según sus atribuciones, las diligencias necesarias para comprobarlos y descubrir a los delincuentes, y recoger todos los efectos, instrumentos o pruebas del delito de cuya desaparición hubiere peligro poniéndolos a disposición de la Autoridad Judicial'. En la misma línea, el art. 11.1 de la Ley Orgánica 2/1986, de 13 de marzo, de Fuerzas y Cuerpos de Seguridad, establece como funciones de éstos, entre otras, f) 'prevenir la comisión de actos delictivos'; g) 'investigar los delitos para descubrir y detener a los presuntos culpables, asegurar los instrumentos, efectos y pruebas del delito, poniéndolos a disposición del Juez o Tribunal competente y elaborar los informes técnicos y periciales procedentes'. 
Por lo demás, se señala que el art. 14 de la Ley Orgánica 1/1992, de 21 de febrero, sobre protección de la seguridad ciudadana, establece que las autoridades competentes podrán disponer las actuaciones policiales estrictamente necesarias para asegurar la consecución de las finalidades previstas en el art. 1 de esta Ley, finalidades entre las que se encuentra la prevención de la comisión de delitos". Según la citada Sentencia (mismo fundamento jurídico) existe, por tanto, "una habilitación legal específica que faculta a la policía para recoger los efectos, instrumentos y pruebas del delito y ponerlos a disposición judicial y para practicar las diligencias necesarias para la averiguación del delito y el descubrimiento del delincuente. Entre esas diligencias (que la Ley no enumera casuísticamente, pero que limita adjetivándolas y orientándolas a un fin) podrá encontrarse la de examinar o acceder al contenido de esos instrumentos o efectos, y en concreto, de documentos o papeles que se le ocupen al detenido, realizando un primer análisis de los mismos, siempre que - como exige el propio texto legal - ello sea necesario (estrictamente necesario, conforme al art. 14 de la Ley Orgánica 1/1992), estricta necesidad que habrá de valorarse atendidas las circunstancias del caso y que ha de entenderse como la exigencia legal de una estricta observancia de los requisitos dimanantes del principio de proporcionalidad. Así interpretada la norma, puede afirmarse que la habilitación legal existente cumple en principio con las exigencias de certeza y seguridad jurídica dimanantes del principio de legalidad, sin perjuicio de una mayor concreción en eventuales reformas legislativas."

En relación a la necesidad de autorización judicial, en esta STC 173/2011, de 7 de noviembre de 2011 se pone de relieve que el criterio general, conforme a la jurisprudencia constitucional, es que sólo pueden llevarse a cabo injerencias en el ámbito de este derecho fundamental mediante la preceptiva resolución judicial motivada que se adecue al principio de proporcionalidad (SSTC 207/1996, de 16 de diciembre, FJ 4; 25/2005, de 14 de febrero, FJ 6; y 233/2005, de 26 de septiembre, FJ 4). Esta regla no se aplica, también según nuestra doctrina, en los supuestos en que concurran motivos justificados para la intervención policial inmediata, que ha de respetar también el principio de proporcionalidad. De manera significativa hemos resaltado en la STC 70/2002, de 3 de abril, que "la regla general es que el ámbito de lo íntimo sigue preservado en el momento de la detención y que sólo pueden llevarse a cabo injerencias en el mismo mediante la preceptiva autorización judicial motivada conforme a criterios de proporcionalidad. De no existir ésta, los efectos intervenidos que puedan pertenecer al ámbito de lo íntimo han de ponerse a disposición judicial, para que sea el juez quien los examine. Esa regla general se excepciona en los supuestos en que existan razones de necesidad de intervención policial inmediata, para la prevención y averiguación del delito, el descubrimiento de los delincuentes y la obtención de pruebas incriminatorias. En esos casos estará justificada la intervención policial sin autorización judicial, siempre que la misma se realice también desde el respeto al principio de proporcionalidad" [FJ 10 b) 3]. Bien entendido que "la valoración de la urgencia y necesidad de la intervención policial ha de realizarse ex ante y es susceptible de control judicial ex post, al igual que el respeto al principio de proporcionalidad. La constatación ex post de la falta del presupuesto habilitante o del respeto al principio de proporcionalidad implicaría la vulneración del derecho fundamental y tendría efectos procesales en cuanto a la ilicitud de la prueba en su caso obtenida, por haberlo sido con vulneración de derechos fundamentales" [FJ 10 b) 5].

En esta línea se cita en esta STC 173/2011, de 7 de noviembre de 2011 la precedente STC 206/2007, de 24 de septiembre, FJ 8, donde ya se decía que "la regla 
general es que sólo mediante una resolución judicial motivada se pueden adoptar tales medidas y que, de adoptarse sin consentimiento del afectado y sin autorización judicial, han de acreditarse razones de urgencia y necesidad que hagan imprescindible la intervención inmediata y respetarse estrictamente los principios de proporcionalidad y razonabilidad". En esta Sentencia razonábamos que no había existido una autorización judicial previa para la injerencia acaecida en el derecho a la intimidad (en este caso un análisis de sangre interesado por la Guardia Civil), entendiéndose como relevante el hecho de que tampoco por los órganos judiciales se había efectuado posteriormente una "ponderación de los intereses en conflicto teniendo en cuenta el derecho fundamental en juego que les condujera a considerar justificada - a la vista de las circunstancias del caso- la actuación policial sin previa autorización judicial" (mismo fundamento jurídico).

Una vez expuesta la doctrina relevante para efectuar el enjuiciamiento que nos ocupa, el siguiente paso del análisis que se lleva a cabo en esta interesante sentencia del Tribunal Constitucional de 7 de noviembre de 2011 lleva a dirigirse a determinar si un ordenador personal puede ser un medio idóneo para el ejercicio de la intimidad personal, resultando entonces necesario para acceder a su contenido el consentimiento de su titular o que se den los presupuestos que legalmente habilitan la intromisión, de acuerdo con los parámetros constitucionales antes desarrollados.

A tal fin se recuerda que el mismo Tribunal Constitucional ha reseñado, ya en su STC 110/1984, de 26 de noviembre, que "la inviolabilidad del domicilio y de la correspondencia, que son algunas de esas libertades tradicionales, tienen como finalidad principal el respeto a un ámbito de vida privada personal y familiar, que debe quedar excluido del conocimiento ajeno y de las intromisiones de los demás, salvo autorización del interesado. Lo ocurrido es que el avance de la tecnología actual y el desarrollo de los medios de comunicación de masas ha obligado a extender esa protección más allá del aseguramiento del domicilio como espacio físico en que normalmente se desenvuelve la intimidad y del respeto a la correspondencia, que es o puede ser medio de conocimiento de aspectos de la vida privada. De aquí el reconocimiento global de un derecho a la intimidad o a la vida privada que abarque las intromisiones que por cualquier medio puedan realizarse en ese ámbito reservado de vida" (FJ 3). En el mismo sentido, en la STC 119/2001, de 24 de mayo, afirmábamos que "estos derechos han adquirido también una dimensión positiva en relación con el libre desarrollo de la personalidad, orientada a la plena efectividad de estos derechos fundamentales. En efecto, habida cuenta de que nuestro texto constitucional no consagra derechos meramente teóricos o ilusorios, sino reales y efectivos ..., se hace imprescindible asegurar su protección no sólo frente a las injerencias ya mencionadas, sino también frente a los riesgos que puedan surgir en una sociedad tecnológicamente avanzada. A esta nueva realidad ha sido sensible la jurisprudencia del Tribunal Europeo de Derechos Humanos, como se refleja en las Sentencias de 21 de febrero de 1990, caso Powell y Rayner contra Reino Unido; de 9 de diciembre de 1994, caso López Ostra contra Reino de España, y de 19 de febrero de 1998, caso Guerra y otros contra Italia” (FJ 5).

En armonía con lo anterior, el Tribunal Constitucional ha venido describiendo casuísticamente una serie de supuestos, en que, con independencia de las libertades tradicionales antes mencionadas, ha podido sobrevenir una injerencia no admisible en el ámbito de la vida privada e íntima de la persona. Así, se afirma que "el derecho a la intimidad comprende la información relativa a la salud física y psíquica de las personas, 
quedando afectado en aquellos casos en los que sin consentimiento del paciente se accede a datos relativos a su salud o a informes relativos a la misma" (SSTC 70/2009, de 23 de marzo, FJ 2 y 159/2009, de 29 de junio, FJ 3). También se ha dicho que "no hay duda de que, en principio, los datos relativos a la situación económica de una persona entran dentro de la intimidad constitucionalmente protegida" (STC 233/1999, de 16 de diciembre, FJ 7), que "en las declaraciones del IRPF se ponen de manifiesto datos que pertenecen a la intimidad constitucionalmente tutelada de los sujetos pasivos" (STC 47/2001, de 15 de febrero, FJ 8), y que "la información concerniente al gasto en que incurre un obligado tributario, no sólo forma parte de dicho ámbito, sino que a través de su investigación o indagación puede penetrarse en la zona más estricta de la vida privada o, lo que es lo mismo, en los aspectos más básicos de la autodeterminación personal del individuo" (STC 233/2005, de 26 de septiembre, FJ 4).

Por otra parte, en la STC 70/2002, de 3 de abril, en que un guardia civil había intervenido a un detenido una agenda personal y un documento que se encontraba en su interior, sostuvimos que "con independencia de la relevancia que ello pudiera tener a los fines de la investigación penal y, por tanto, de su posible justificación, debemos afirmar que la apertura de una agenda, su examen y la lectura de los papeles que se encontraban en su interior supone una intromisión en la esfera privada de la persona a la que tales efectos pertenecen, esto es, en el ámbito protegido por el derecho a la intimidad, tal como nuestra jurisprudencia lo define" (FJ 10). Finalmente, cabe recordar que en la STC 14/2003, de 28 de enero, FJ 6, afirmamos que la reseña fotográfica de un detenido, obtenida durante su permanencia en dependencias policiales, "ha de configurarse como un dato de carácter personal", respecto del cual los miembros de las fuerzas y cuerpos de seguridad del Estado "están obligados en principio al deber de secreto profesional".

Si no hay duda de que los datos personales relativos a una persona individualmente considerados, a que se ha hecho referencia anteriormente, están dentro del ámbito de la intimidad constitucionalmente protegido, menos aún entiende el Tribunal Constitucional en esta STC 173/2011, de 7 de noviembre de 2011que pueda haberla de que el cúmulo de la información que se almacena por su titular en un ordenador personal, entre otros datos sobre su vida privada y profesional (en forma de documentos, carpetas, fotografías, vídeos, etc.) - por lo que sus funciones podrían equipararse a los de una agenda electrónica-, no sólo forma parte de este mismo ámbito, sino que además a través de su observación por los demás pueden descubrirse aspectos de la esfera más íntima del ser humano. Es evidente que cuando su titular navega por Internet, participa en foros de conversación o redes sociales, descarga archivos o documentos, realiza operaciones de comercio electrónico, forma parte de grupos de noticias, entre otras posibilidades, está revelando datos acerca de su personalidad, que pueden afectar al núcleo más profundo de su intimidad por referirse a ideologías, creencias religiosas, aficiones personales, información sobre la salud, orientaciones sexuales, etc. Quizás, estos datos que se reflejan en un ordenador personal puedan tacharse de irrelevantes o livianos si se consideran aisladamente, pero si se analizan en su conjunto, una vez convenientemente entremezclados, no cabe duda que configuran todos ellos un perfil altamente descriptivo de la personalidad de su titular, que es preciso proteger frente a la intromisión de terceros o de los poderes públicos, por cuanto atañen, en definitiva, a la misma peculiaridad o individualidad de la persona. A esto debe añadirse que el ordenador es un instrumento útil para la emisión o recepción de correos electrónicos, pudiendo quedar afectado en tal caso, no sólo el derecho al secreto de las comunicaciones del art. 18.3 CE (por cuanto es indudable que la 
utilización de este procedimiento supone un acto de comunicación), sino también el derecho a la intimidad personal (art. 18.1 CE), en la medida en que estos correos o email, escritos o ya leídos por su destinatario, quedan almacenados en la memoria del terminal informático utilizado. Por ello deviene necesario establecer una serie de garantías frente a los riesgos que existen para los derechos y libertades públicas, en particular la intimidad personal, a causa del uso indebido de la informática así como de las nuevas tecnologías de la información.

En este mismo sentido la STC 173/2011, de 7 de noviembre de 2011 recuerda que diversas disposiciones tomadas a nivel europeo se han ocupado de esta materia. Así en primer lugar el Convenio núm. 108 del Consejo de Europa sobre protección de los datos informatizados de carácter personal (1981), vinculante para España, y las recomendaciones del Comité de Ministros que lo desarrollan, en particular, la recomendación sobre datos personales utilizados en el sector policial (1987) y la recomendación sobre privacidad en Internet (1999). El preámbulo de esta última recomendación - $\mathrm{R}(99)$ 5, de 23 de febrero de 1999- pone de relieve que "el desarrollo de las tecnologías y la generalización de la recogida y del tratamiento de datos personales en las 'autopistas de la información' suponen riesgos para la intimidad de las personas naturales" y que "las comunicaciones con ayuda de las nuevas tecnologías de la información están también sujetas al respeto de los derechos humanos y de las libertades fundamentales, en concreto al respeto a la intimidad y del secreto de las comunicaciones, tal y como se garantizan en el artículo 8 de la Convención Europea de los Derechos Humanos". Además, recuerda esta recomendación que "el uso de Internet supone una responsabilidad en cada acción e implica riesgos para la intimidad" (introducción), por cuanto cada visita a un sitio de Internet deja una serie de "rastros electrónicos" que pueden utilizarse para establecer "un perfil de su persona y sus intereses" (apartado II, 2), subrayando también que la dirección de correo electrónico constituye "un dato de carácter personal que otras personas pueden querer utilizar para diferentes fines" (apartado II, 6).

En este mismo orden de cosas se recuerda que la acción normativa desarrollada por la Unión Europea, entre la que destaca, además de la consagración del derecho a la protección de los datos personales realizada por el art. 8 de la Carta de Derechos Fundamentales de la Unión Europea, la Directiva 2002/58/CE del Parlamento Europeo y del Consejo de 12 de julio de 2002 relativa al tratamiento de los datos personales y a la protección de la intimidad en el sector de las comunicaciones electrónicas, cuyo considerando núm. 6 resalta que "Internet está revolucionando las estructuras tradicionales del mercado al aportar una infraestructura común mundial para la prestación de una amplia gama de servicios de comunicaciones electrónicas. Los servicios de comunicaciones electrónicas disponibles al público a través de Internet introducen nuevas posibilidades para los usuarios, pero también nuevos riesgos para sus datos personales y su intimidad". Además, recuerda en su considerando núm. 24 que "los equipos terminales de los usuarios de redes de comunicaciones electrónicas, así como toda información almacenada en dichos equipos, forman parte de la esfera privada de los usuarios que debe ser protegida de conformidad con el Convenio Europeo para la protección de los Derechos Humanos y de las Libertades Fundamentales", advirtiendo que "los denominados programas espías (Spyware), web bugs, identificadores ocultos y otros dispositivos similares pueden introducirse en el terminal del usuario sin su conocimiento para acceder a información, archivar información oculta o rastrear las 
actividades del usuario, lo que puede suponer una grave intromisión en la intimidad de dichos usuarios".

También son singularmente relevantes las resoluciones del Parlamento Europeo de 17 de septiembre de 1996 y de 17 de diciembre de 1998, ambas sobre el respeto de los derechos humanos en la Unión Europea, la primera en cuanto dispone en su apartado 53 que "el respeto de la vida privada y familiar, de la reputación, del domicilio y de las comunicaciones privadas, tanto de las personas físicas como jurídicas, así como la protección de datos de carácter personal son derechos fundamentales básicos respecto de los cuales los Estados miembros deben ejercer una especial protección, habida cuenta de la incidencia negativa que sobre los mismos tienen las nuevas tecnologías y que sólo la armonización de las legislaciones nacionales en la materia, confiriendo una alta protección, es susceptible de responder a este desafío", y la segunda, al subrayar en su apartado 23 que "el derecho al respeto de la vida privada y familiar, del domicilio y de la correspondencia, así como a la protección de los datos de carácter personal, representan derechos fundamentales que los Estados tienen la obligación de proteger y que, por consiguiente, toda medida de vigilancia óptica, acústica o informática deberá adoptarse dentro de su más estricto respeto y acompañada en todos los casos de garantías judiciales".

El Tribunal de Justicia de la Unión Europea ha reafirmado también la importancia del derecho a la protección de los datos personales como un elemento a tomar en consideración no sólo en el momento de transponer una directiva sino también cuando las autoridades estatales y los órganos judiciales nacionales procedan a su aplicación [entre otras, Sentencia del Tribunal de Justicia (Gran Sala) de 29 de enero de 2008, asunto C-275/06, Productores de Música de España (Promusicae) c. Telefónica de España, S.A.U., apartados 61-70]. Por su parte, el Tribunal Europeo de Derechos Humanos ha venido asumiendo una interpretación extensiva del concepto "vida privada" del art. 8 del Convenio europeo para la protección de los derechos humanos y de las libertades fundamentales. Así, su Sentencia de 16 de febrero de 2000, dictada en el caso Amann contra Suiza, considera que "el término 'vida privada' no se debe interpretar de forma restrictiva", de forma que éste "engloba el derecho del individuo de crear y desarrollar relaciones con sus semejantes", sin que "ninguna razón de principio permita excluir las actividades profesionales o comerciales" (§ 65). De manera específica, la STEDH de 3 de abril de 2007, caso Copland contra el Reino Unido, considera en su $\S 41$ que están incluidos en el ámbito de protección del art. 8 del Convenio europeo, por cuanto pueden contener datos sensibles que afecten a la intimidad, tanto "los correos electrónicos enviados desde el lugar del trabajo" como "la información derivada del seguimiento del uso personal de Internet". En este caso, precisa el Tribunal, a la demandante no se le advirtió de que podría ser objeto de un seguimiento, por lo que podía razonablemente esperar que se reconociera el carácter privado "en lo que respecta al correo electrónico y la navegación por Internet" ( $§ 42)$. Por su parte, la STEDH de 22 de mayo de 2008, caso Iliya Stefanov contra Bulgaria, consideró que el registro de la oficina de un Abogado, incluyendo los datos electrónicos, equivale a una injerencia en su "vida privada", lesiva por ello del art. 8 del Convenio (\$ 34). No obstante reconocer el Tribunal que concurría en este caso un objetivo legítimo (investigación penal por delito de extorsión) y que existía una previa autorización judicial, siendo así que "los registros del PC y las incautaciones deben, por regla general, llevarse a cabo en virtud de una orden judicial" (§ 39), razona que la expresada orden se había elaborado en términos excesivamente amplios, ejecutándose 
además de manera desproporcionada por la policía, por lo que se había afectado al secreto profesional, por cuanto "retiró todo el equipo del solicitante, incluyendo sus accesorios, así como todos los disquetes que se encontraban en su oficina", resultando que durante el tiempo que permaneció este material en su poder "ningún tipo de garantías existen para asegurar que durante el periodo intermedio el contenido completo del disco duro y los discos no fueron inspeccionados o copiados" (§ 42). De lo expuesto, parece desprenderse que cualquier injerencia en el contenido de un ordenador personal - ya sea por vía de acceso remoto a través de medios técnicos, ya, como en el presente caso, por vía manual- deberá venir legitimada en principio por el consentimiento de su titular, o bien por la concurrencia de los presupuestos habilitantes antes citados.

Tal conclusión, por otra parte, parece desprenderse, si bien de manera indirecta, del contenido de la Sentencia del Tribunal Constitucional 34/2009, de 9 de febrero, en la que se aprecia que no se había infringido por el órgano judicial el principio de legalidad penal al haber condenado al demandante por un delito de descubrimiento y revelación de secretos, cuyo bien jurídico protegido es la intimidad, resultando como hechos probados que éste había accedido al ordenador de una compañera de trabajo y había procedido a la lectura de sus mensajes de correo electrónico. En particular, se reseñaba que "[d]esde la estricta perspectiva de control que corresponde a este Tribunal en modo alguno cabe tildar a la vista del tipo penal previsto del art. 197.1 y 2 CP de aplicación analógica o in malam partem, carente de razonabilidad por apartarse de su tenor literal o por utilización de pautas extravagantes o criterios no aceptados por la comunidad jurídica la llevada a cabo por la Audiencia Provincial, al considerar documentos personales e íntimos la libreta de direcciones y de teléfonos de la denunciante, accediendo por este medio a la dirección de su correo electrónico y subsumir en aquel tipo penal el acceso a dichos documentos sin el consentimiento de su titular, obteniendo de esta forma datos de carácter personal de aquella y de sus compañeros, que es la conducta por la que ha sido condenado el recurrente de amparo" (FJ 6). A la misma conclusión se llegó respecto del acceso a los datos almacenados en un teléfono móvil en la STC 230/2007, de 5 de noviembre, si bien declarando vulnerado en tal caso el art. 18.3 CE al haberse accedido por la Guardia Civil al registro de llamadas memorizado en el terminal intervenido al recurrente, confeccionando un listado de llamadas recibidas, enviadas y perdidas, sin su consentimiento ni autorización judicial (FJ 2).

Pues bien, tras esta interesante pronunciamiento, y, sobre todo, las importantes referencias a la precedente doctrina constitucional y normas europeas por parte del Tribunal Constitucional en la citada STC 173/2011, de 7 de noviembre de 2011quiero ahora referirme a dos recientes decisiones que creo que pueden ser bien ilustrativas de la evolución hacia el futuro de su doctrina, en primer lugar la sentencia del Tribunal Constitucional (STC) 176/2013, de 21 de octubre, que concluye que la publicación de varias fotografías, en un programa de televisión, de Francisco Álvarez-Cascos cuando era ministro de Fomento, en 2004, en compañía de su entonces pareja sentimental, María Porto, tomadas durante sus vacaciones y en lugares públicos, tanto en la terraza cuanto en la playa de un hotel de Lanzarote, habían vulnerado el derecho a la intimidad y a la propia imagen de ambas personas.

Sobre el particular, ya hemos comprobado que es doctrina consolidada del propio Tribunal Constitucional que el derecho a la intimidad «tiene por objeto 
garantizar al individuo un ámbito reservado de vida frente a la acción y el conocimiento de los demás», y en este caso concreto se ha considerado que es de aplicación plena la reserva de ese ámbito íntimo al conocimiento de los demás a la situación descrita en que Álvarez-Cascos estaba acompañado de María Porto en espacios públicos, ante el resto de clientes del hotel -huéspedes, empleados, paseantes o clientes en general-, considerando digna de protección con fundamento en su derecho a la intimidad y la privación «al conocimiento de los demás» su actuación con fundamento en que estaba acompañado de menores y de otra persona, María Porto, sin relevancia pública a pesar de que no tenían cuidado alguno en mantener su presencia reservada del mundo exterior.

La sentencia en concreto concluye que se ha vulnerado también el derecho de ambas personas a la propia imagen y sobre el particular hay que recordar que en efecto la Ley Orgánica de Protección Civil del Derecho al Honor, a la Intimidad Personal y Familiar y a la Propia Imagen (LOPC) considera intromisión ilegítima la captación y publicación de imágenes de personas privadas, en contra de su voluntad, aunque se hayan tomado en lugares públicos (art. $7^{\circ} .5$ ) y que a continuación por lo que atañe a personalidades notorias, se puntualiza en el art. $8^{\circ} .2$ a), que «En particular, el derecho a la propia imagen no impedirá: a) Su captación, reproducción o publicación por cualquier medio, cuando se trate de personas que ejerzan un cargo público o una profesión de notoriedad o proyección pública y la imagen se capte durante un acto público o en lugares abiertos al público».

Pues bien, hay que señalar hacia el futuro que también, como en el caso debatido en esta sentencia, en el supuesto de las fotografías tomadas en «un lugar abierto al público» a una persona, como Alvarez Cascos, que «ejercía un cargo público», se considerar ilícita la captación de las imágenes tomadas en el hotel en Lanzarote, porque, además de quien ejercía ese cargo público en las imágenes aparece otra persona, a la que sí que se le podría otorgar sin duda el amparo pero en todo caso se hace extensible también a la persona que ejercía el cargo público anulando la precedente STS (Sala $1^{\mathrm{a}}$ ) 719/2009, de 16 de diciembre, bajo ponencia de Juan Antonio Xiol, actual magistrado del Tribunal Constitucional, que había estimado que la publicación de esas fotografías estaba amparada por la libertad de información sobre el fundamento de que «la presencia de una persona que aparecía con el personaje público afectado tenía carácter accesorio y resultaba necesaria para transmitir la información».

En apoyo de la doctrina constitucional anteriormente anunciada se cita una vez más la sentencia del Tribunal Europeo de Derechos Humanos de Estrasburgo (STEDH) de 24 de junio de 2004 (caso Hannover), donde se consideró ilegitima la publicación en Alemania de fotografías de Carolina de Mónaco y Ernesto de Hannover, en lugares públicos haciendo deportes, paseando o de vacaciones, por la razón de que Carolina y sus acompañantes eran solamente «personas notorias», que no desempeñaban funciones políticas, afirmando el TEDH, sin embargo, que sería distinta la conclusión si las fotografías hubieran reproducido imágenes de personas que ejercen funciones públicas, ya que «existe un derecho del público a ser informado, derecho esencial en una sociedad democrática que puede incluso referirse a aspectos de la vida privada de personas públicas, concretamente cuando se trata de personalidades de la política».

Otra posterior sentencia del TC 19/2014, de 10 de febrero también anula la sentencia 125/2011 de la Sala 1 del TS, igualmente siendo ponente el actual magistrado 
del Tribunal Constitucional Juan Antonio Xiol, y otorga el amparo a la actriz Melani Olivares, sobre la cual una revista había publicado varias fotografías en topless en una playa de Ibiza concluyendo que la difusión de esas fotografías ha lesionado el derecho a la propia imagen de la actriz sin que el ejercicio de la libertad de expresión desarrollada por profesionales de la información pueda prevalecer sobre el derecho de la afectada a la propia imagen, ya que, con la publicación de las fotografías, no se «contribuye a la formación de la opinión pública», porque se trata de una información que «no es estrictamente de carácter político, económico, cultural o científico, sino meramente de entretenimiento», y «porque no cabe identificar indiscriminadamente interés público con interés del público, o de sectores del mismo ávido de curiosidad», citando de nuevo la referida STEDH (Sección 3 ${ }^{\text {a }}$ ) de Hannover de 2004, aunque hay otra STEDH (Pleno) de 7 de febrero de 2012 donde se estima que no han vulnerado ni el derecho de intimidad ni el de imagen de Carolina de Mónaco ni de su entonces marido Ernesto de Hannover las revistas alemanas que publicaron fotografías de los mismos durante sus vacaciones de esquí en las estaciones invernales, porque se distingue entre personas privadas, por una parte, y públicas, por otra, en las que incluye, no sólo a los políticos, sino también a aquéllas que tienen una proyección notoria, de suerte tal que la existencia de un «interés general», sobre fotografías o artículos de prensa se extiende «no solamente cuando la publicación se refiere a cuestiones políticas o crímenes cometidos, sino también cuando se refiere a cuestiones relativas al deporte o a actores», por lo que, tanto Carolina de Mónaco como Ernesto Hannover, «habida cuenta de su grado de notoriedad irrefutable... deben ser considerados personajes públicos», igualando esta STEDH de 2012 «a las personas que actúan en un ámbito público, como personalidades de la política o personajes públicos», y asumiendo el criterio del TS alemán de que «la libertad de expresión también comprende los reportajes de entretenimiento», lo que debe ser tomado en justa consideración también hacia el futuro de la doctrina constitucional antes expuesta.

Por otro lado, en aplicación de la Ley Orgánica 1/1982 de protección civil de los derechos al honor, a la intimidad personal y familiar y a la propia imagen, en uno de los primeros casos, el Tribunal Supremo opinó que la difusión de las imágenes de la muerte del torero Paquirri era de interés general [STS 1 ${ }^{\mathrm{a}}$, 28.10.1986 (Ar. 6015; MP: Cecilio Serena Velloso)]:

"No son tales imágenes, obtenidas en el momento mismo del ingreso en la enfermería,sino el final del espectáculo y las palabras del infortunado diestro puesto en trance tan apretado que poco después perdería la vida a causa de las heridas filmadas, no pueden ser interpretadas como una apelación a su intimidad, de modo tal, que si los usos sociales y la índole propia de la actividad profesional no excluían de suyo aquellos momentos de la connatural publicidad, tampoco lo fueron por la decisión de la persona de que se trata, anuente a la honrosa celebridad que le proporcionaba su desgracia, a la que hacía frente con serenidad poco común" (FD $7^{\circ}$ ).

En cambio, sobre el mismo asunto el Tribunal Constitucional entendió que tales imágenes no gozaban de tal interés general, pues "ello supondría convertir en instrumento de diversión y entretenimiento algo tan personal como los padecimientos y la misma muerte de un individuo" [STC 231/1988, Sala Segunda, 2.12.1988, FJ $8^{\circ}$ (MP: Luis López Guerra)], sin que, con todo, quede bien delimitado el perfil del derecho a la propia imagen (realmente el asunto estudiado) y lo que es derecho a la intimidad. 
El tema objeto de nuestra atención tiene, por su parte, mucha controversia en caso de personas con relevancia pública y la pretendida protección de los derechos de las personalidades, como en uno de los casos Tous-Montiel [STC 197/1991, Sala Sgunda, de 17.10.1991 (MP: Miguel Rodríguez-Piñero y Bravo-Ferrer)]:

"Aunque el derecho a la intimidad, como límite a la libertad de información, deba ser interpretado restrictivamente, ello no supone que los personajes públicos, por el hecho de serlo, y aún menos sus familiares, hayan de ver sacrificado ilimitadamente su derecho a la intimidad (...) Las personas que, por razón de su actividad profesional ,como aquí sucede, son conocidas por la mayoría de la sociedad, han de sufrir mayores intromisiones en su vida privada que los simples particulares, pero ello no puede ser entendido tan radicalmente, como se sostiene en la demanda, en el sentido de que el personaje público acepte libremente el «riesgo de lesión de la intimidad que implica la condición de figura pública»"( $\left.\mathrm{FJ} 4^{\circ}\right)$.

La opinión se mantiene en muchas otras sentencias [por ejemplo, la STS, $1^{\text {a }}$, 6.11.2003 (Ar. 8268; MP: Jesús Corbal Fernández)], afirmando los tribunales que si la información no tiene interés público y viola la intimidad, puede ser considerada como una intromisión ilegitima, a pesar de la notoriedad de la persona, como pasó en el caso Preysler [STC 115/2000, Sala Segunda, 5.5.2000 (MP: Julio Diego González Campos)], confirmada posteriormente por el TEHD

Respecto a esta sentencia, a pesar de que podría alegarse - como hizo el Supremo para negar la vulneración del derecho a la intimidad- que la información únicamente ponía de manifiesto detalles nimios de la vida de Isabel Preysler, lo cierto es que, al haber sido revelados los hechos por una persona que trabajaba para ella, estaban sujetos a una obligación de mantener la reserva,tal como se contempla en el art. 7.4 de la LO 1/1982. Y la obligación se da para personas públicas al igual que las privadas.

Las personas públicas no se equiparan totalmente a las privadas, puesto que la jurisprudencia habla de que han de sufrir mayores intromisiones en su vida privada o que ven reducida su esfera de intimidad. Ahora bien, "mayores intromisiones" no significa privarles de los derechos, no hay nada en la Constitución que legitime esta privación. Si lo revelado es innecesario para la información y critica relacionada con el desempeño del cargo público, la actividad profesional dela persona o la información que previamente ha difundido "ese personaje es, a todos los efectos, un particular como otro cualquiera que podrá hacer valer su derecho al honor, a la intimidad o a la propia imagen frente a esas opiniones, críticas o informaciones lesivas" [STC 134/1999, SalaPrimera, 15.7.1999, FJ $7^{\circ}$ (MP: María Emilia Casas Baamonde), que cita muchas otras].

Las personas privadas pueden sufrir intromisiones en sus derechos a la intimidad y a la propia imagen derivadas de la existencia de un interés público, si bien estas intromisiones son necesariamente menores que las que soportan las personas públicas, tal como se desprende de la doctrina del Tribunal Constitucional (STC 197/1991, antes citada).

La STC 20/1992, Sala Primera, 14.2.1992 (MP: Francisco Tomás y Valiente), relativa a la identificación de una persona que padecía SIDA, es una de las más interesantes a nuestro entender. La sentencia rechaza que se argumente que los datos 
publicados eran veraces - ello no legitima la intromisión en la intimidad- y reafirma que para poderse publicar sobre hechos privados de una persona sin su consentimiento lo informado ha de ser de interés público, lo cual no se daba en el caso, y ello provocaba al enfermo un importante daño. La sentencia se utiliza después en jurisprudencia de las Audiencias Provinciales para fundamentar condenas a medios de comunicación que revelan que alguna persona padece tal enfermedad (véase, por ejemplo, la SAP Cáceres, Civil, Sec. $1^{\mathrm{a}}$, 26.4.2004).

Sobre personas privadas que han tenido la desgracia de sufrir una agresión: no son protegibles las publicaciones que revelan de forma innecesaria aspectos relevantes de la vida personal y familiar de una joven agredida sexualmente, revelando incluso su identidad y la circunstancia de su virginidad [STC 185/2002,Sala Segunda, 14.10.2002 (MP: Tomás S. Vives Antón)]; ni es protegible la publicación de datos sobre un juicio que permiten identificar a la victima -menor de edad- de una agresión sexual llevada a cabo por su padre [STC 127/2003, Sala Segunda, 30.6.2003 (MP: Pablo Manuel Cachón Villar)].

De todas formas la distinción entre personas públicas y privadas a la hora de establecer la protección de los derechos de la personalidad es más importante en el derecho al honor que en los derechos a la intimidad y a la propia imagen, tal como creemos que se desprende por ejemplo en la sentencia del TEDH del caso Hannover, ya citado ; es cierto, como nos dice el Constitucional, que las personas públicas han de sufrir mayores intromisiones, pero ambos tipos de personas son titulares de los derechos y será más importante el concepto de interés público para legitimar la intromisión que otro tipo de consideraciones. Y esta cuestión vamos a ver a continuación.

Aunque la LO 1/1982 no habla para nada de este tema, el concepto de interés público es el básico para delimitar hasta donde se puede llegar con una información. Esta noción autoriza o no la intromisión, permite que prevalezca el derecho a la libertad de información del art. $20 \mathrm{CE}$ - que es obvio recordarlo pero también es un derecho fundamental - o los derechos a la personalidad del art. 18.

Interés público no es "interés del público", no existe un supuesto derecho al cotilleo que legitimelas intromisiones ilícitas: "la relevancia comunitaria y no la simple satisfacción de la curiosidadajena (...) es lo único que puede justificar la exigencia de que se asuman aquellas perturbacioneso molestias ocasionadas por la difusión de una determinada noticia” [STC 232/1993, Sala Segunda, 12.7.1933 (MP: Álvaro Rodríguez Bereijo)].

Ni el cotilleo ni el interés morboso juegan aquí: no puede asumirse que sea de interés general ni contribuyan a formar una opinión pública informaciones que violando además el secreto profesional sanitario - revelen por ejemplo que una persona sufre una grave enfermedad, como por ejemplo el SIDA; en este sentido puede verse la STS, 1a , 9.3.2006 (Ar. 5413; MP: Ignacio Sierra Gil de la Cuesta). En esta resolución se enjuiciaba la publicación por parte de la revista Tribuna del hecho de que una conocida actriz padecía tal dolencia; el Supremo deja claro que no había interés general alguno en la información publicada y que "el tratamiento informativo dado por la revista tiene que ver con el sensacionalismo y con la satisfacción de la curiosidad morbosa, y no propiamente con un pretendido interés de información general” $\left(\mathrm{FD} 4^{\circ}\right)$. 
Es interesante destacar de tal sentencia el hecho de que el Supremo considera que se ha dado una violación no sólo del derecho a la intimidad - al revelar la posible existencia de la enfermedad (no confirmada) -, sino también del derecho al honor, ya que en 1990, fecha de publicación de la revista , la divulgación del hecho de que alguien padecía el SIDA era una grave descalificación moral para quien la padeciera (hecho afortunadamente superado ahora nos dice el Tribunal) por lo que "dada la gran carga desvalorativa que conlleva la divulgación de ese sufrimiento, superala mera infracción del derecho a la intimidad para constituir también un atentado al derecho alhonor, por cuanto supone un desmerecimiento en la consideración ajena"(FD $\left.4^{\circ}\right)$.

Y no hay interés público alguno en revelar datos personales de las víctimas de agresiones sexuales (SSTC citadas en el punto anterior), el pronunciamiento de los tribunales aquí es tajante:"en modo alguno puede exigirse a nadie que soporte pasivamente la difusión periodística de datos tan relevantes sobre su vida privada cuyo conocimiento es trivial e indiferente para el interés público. Porque es notorio que la identificación de la victima de la agresión fue, en elsentido más propio de las palabras, irrelevante a efectos de la información que se quiso transmitir" (STC 185/2002 citada)

Por otra parte en un mismo supuesto pueden darse aspectos de interés público (información protegida), y otros que no lo son (no protegida), así en el asunto AlcocerKoplowitz la STS, 1 a , 8.5.1999 (Ar. 4252; MP: Antonio Gullón Ballesteros): “(...) hay que distinguir entre la publicación de unos rumores insistentes de crisis matrimonial y los aspectos internos de esa crisis (...) La publicación del rumor de crisis matrimonial y de que el matrimonio estaba al borde de la ruptura poseía un evidente interés general por los cuantiosos intereses económicos afectados en caso de una división del patrimonio conyugal. Es un hecho publico y notorio la relevante personalidad en el mundo de las finanzas de D. Alberto A. T. y D. ${ }^{a}$ Esther K. (...) No puede decirse lo mismo de la publicación de causas de la crisis matrimonial (que el reportaje titulaba "Los rumores sobre un hijo secreto enturbian la relación matrimonial ", además de problemas médicos de una hija menor del matrimonio). Tales causas, verdaderas o falsas, no interesan en absoluto para la formación de una opinión pública sana ni a los intereses generales, forman parte de la intimidad y honor de las personas que en ningún modo puede ser aireada sin su consentimiento (...)" (FD $\left.1^{\circ}\right)$.

El permitir que la persona que haya sufrido una intromisión en su intimidad reaccione frente a la misma exigiendo que se hable más sobre el tema y que se difunda su versión no tiene sentido; esé ste un punto en que se diferencia claramente el derecho al honor respecto al de intimidad.

La LO 1/1982 habla efectivamente de que la tutela judicial frente a las intromisiones comprende entre otras - la medida del reconocimiento del derecho a réplica (art. 9.2), pero si ya se ha violado el derecho a la intimidad, continuar hablando del tema- aunque sea la versión de la victima- no hace sino revelar más hechos privados e incidir en los aspectos que nunca se debieron haber hecho públicos, ya que lo principal para proteger este derecho es mantener la información alejada de la exposición pública, aunque la información sea verdadera.

La esencia de la protección del derecho a la intimidad no es, como en el derecho al honor, el hecho de que responder por las falsedades de lo publicado: aquí se responde 
precisamente por decir la verdad. La jurisprudencia recalca a menudo - frente a las alegaciones de algunos medios de comunicación de que lo que publican se ajusta a la verdad - que es irrelevante la veracidad de la información si ésta transgrede el limite del derecho a la intimidad (art.20.4 CE en relación con el 18.1 CE).

Así, en uno de los casos Tous-Montiel (STC 134/1999 citada), sobre la publicación de hechos relativos a la adopción de los hijos de una conocida pareja de personajes públicos, el Tribunal admite que efectivamente toda la información publicada es veraz, sin que además se contengan expresiones injuriosas o innecesarias sobre lo narrado, pero ello- que supone que no hay intromisión en el honor- ha de analizarse en el contexto del derecho a la intimidad de los menores : "sólo resta, para comprobar si la información goza o no de protección constitucional, examinar si se ha extralimitado por injerir en la vida privada personal y familiar", especificándose que "Lo que el art. 18.1 garantiza es un derecho al secreto, a ser desconocido, a que los demás no sepan que somos o lo que hacemos, vedando que terceros, sean particulares o poderes públicos, decidan cuáles sean los lindes de nuestra vida privada, pudiendo cada persona reservarse un espacio resguardado de la curiosidad ajena, sea cuál sea lo contenido en ese espacio.

Del precepto constitucional se desprende que el derecho a la intimidad garantiza al individuo un poder jurídico sobre la información relativa a su persona o a la de su familia, pudiendo imponer a terceros su voluntad de no dar a conocer dicha información o prohibiendo su difusión no consentida (...)" (FJ $\left.5^{\circ}\right)$.

En este asunto, el interés de ambos menores en que no se divulguen datos sobre su vida privada y familiar impone un límite a las libertades de expresión e información, "sin que la supuesta veracidad de lo revelado exonere al medio de comunicación de responsabilidad por la intromisión en la vida privada de ambos menores. En estos casos el que la información sea o no veraz (...) es irrelevante" $\left(\mathrm{FJ} 6^{\circ}\right)$.

En el mismo sentido se considera irrelevante la veracidad de lo publicado y se condena por intromisiones en la vida privada de las personas como la difusión de la noticia de que un conocido preso que pretendía congelar su semen [STS, 1 ${ }^{\mathrm{a}}$, 7.7.2004 (Ar. 4945; MP: Alfonso Villagómez Rodil)], o publicar que un piloto de un avión que sufrió un accidente era un hombre casado con hijos que vivía con otra mujer, azafata, quien se encontraba embarazada [STC 172/1990,Sala Segunda, 12.11.1990 (MP: Eugenio Díaz Eimil)], así como revelar los datos de la alteración cromosómica de una atleta [STS, 1 1 , 13.3.1989 (Ar.2040; MP: Juan Latour Brotons)] o publicar que una persona tenía el SIDA [STC 20/1992 y STS, $1^{\text {a }}$, 9.3.2006, ya citadas].

La LO 1/1982 contiene dos supuestos de intromisión ilegítima en el derecho a la propia imagen; uno, la utilización de la imagen de una persona para fines publicitarios, comerciales o de naturaleza análoga (art. 7.6), y dos, la captación, reproducción o publicación de la imagen de una persona en lugares o momentos de su vida privada o fuera de ellos (art. 7.5 en relación con el art. 8.2). El primero de los dos supuestos constituye el ámbito patrimonial del derecho, y de acuerdo con la doctrina del Tribunal Constitucional (STC 231/1988, ya citada) no tiene protección constitucional, sólo civil, ya que constituye un derecho civil ordinario. 
Respecto a la captación, reproducción o publicación de la imagen de la persona en lugares o momentos de su vida privada o fuera de ellos, se impide la misma salvo las tres excepciones previstas en la Ley:

a) Si se trata de personas públicas y su imagen se capta durante un acto público o en lugares abiertos al público;

b) La utilización de la caricatura de dichas personas, de acuerdo con el uso social;

c) La información gráfica sobre un suceso público cuando la imagen de una persona determinada aparezca como meramente accesoria.

La jurisprudencia rechaza en ocasiones la aplicación de la primera excepción, protegiendo el derecho a la imagen de las personas públicas aunque la imagen haya sido tomada en un lugar público, si aquéllas habían buscado tal lugar considerando que en el mismo tenían una cierta expectativa de encontrarse en privado: STS, 1 ${ }^{\mathrm{a}}$, 29.3.1988 (Ar. 2480; MP: Juan Latour Brotons); y SSTC 139/2001, Sala Primera, 18.6.2001 (MP: Pablo Manuel Cachón Villar) y 83/2002, Sala Primera, 22.4.2002 (MP: Pablo García Manzano).

En este sentido también en Alemania se ha realizado esta ampliación del espacio de protección de la imagen de las personas públicas (Bundesgerichtshof, Sentencia de 19.12.1995, asunto Carolina de Mónaco).

El derecho a la propia imagen se confunde a menudo con el de la intimidad y la confusión es hasta cierto punto lógica porque hablamos de un aspecto del derecho relacionado con la vida privada (frente al otro aspecto relacionado con aspectos comerciales) y porque muchas veces se dan violaciones conjuntas de los dos derechos. De hecho el ámbito anglosajón se solapan - como en el caso Campbell-, pero todo ello no debe llevarnos a confundirlos en el derecho español; donde el derecho a la propia imagen tiene una doble vertiente, el aspecto personal y el patrimonial, y el primero está relacionado claramente con la intimidad y así apareció históricamente en la jurisprudencia anglosajona de principios de siglo. Pero, relacionados o no, son dos derechos diferentes.

La protección del derecho a la propia imagen es cada vez más importante y en tal sentido la STS, 1a , 7.3.2006 (Ar. 1579; MP: Francisco Marín Castán) habla de que la jurisprudencia del Tribunal Supremo en esa materia "se caracteriza por su rigor al considerar ilegítima la publicación inconsentida de la imagen de una persona desnuda o semidesnuda incluso cuando se trate de un personaje público y aun cuando sí hubiera mediado consentimiento para la mera captación de la imagen, pues el pudor sigue siendo un sentimiento socialmente estimable" ( $\left.\mathrm{FJ} \mathrm{4}^{\circ}\right)$, recomendando la lectura de un interesante voto particular a la STS, 1ª 30.1 .1998 (Ar. 358; MP: Alfonso Villagómez Rodil).

$\mathrm{Y}$, al igual que en el derecho a la intimidad, no se legitima la intromisión en la imagen por ningún supuesto derecho al cotilleo; de manera que la sentencia que acabamos de mencionar condena a una revista porque considera "que el fotomontaje publicado no es más que la manipulación de la imagen de una persona conocida para 
excitar la curiosidad malsana de los potenciales lectores de la revista, puesto que se aprovechaba el rostro de aquella para, en definitiva, ofrecerla públicamente de un modo habitualmente preservado por la demandante a la curiosidad ajena" (FJ $\left.4^{\circ}\right)$.

De "curiosidad malsana" nos habla pues el Supremo, como un concepto que no impide que se cometa la intromisión ilegítima; recordemos aquí la diferencia de la que hablábamos, al tratar el derecho a la intimidad, entre "interés público" e "interés del público".

Hemos recogido algunos ejemplos en que los tribunales consideran que no hay interés general en el conocimiento de determinadas imágenes de personajes famosos o no; fotografías de la demandante, una conocida actriz, junto con su entonces novio, un aristócrata italiano, en la cama [STS, 1 ${ }^{\mathrm{a}}, 11.11 .2004$ (Ar. 6660; MP: Alfonso Villagómez Rodil)]; publicación de fotografías de una famosa probándose prendas de baño en el interior de un probador [STS, 1 ${ }^{\mathrm{a}}$, 22.3.2001 (Ar. 4751; MP: Alfonso Villagómez Rodil)]; fotografías de una mujer desnuda en un reportaje sobre las sectas, aunque perteneciera a una secta que fomenta la promiscuidad sexual -ello no le hace perder el poder de reserva sobre partes íntimas de su cuerpo- [STC 156/2001, Sala Segunda, 2.7.2001 (MP: Carles Viver Pi-Sunyer)]; fotografías de dos personas famosas tomadas en una reserva de caza en Kenia, obtenidas por un pariente del recurrente [STC 139/2001, ya citada]; fotografías de un conocido financiero besándose con una mujer en una playa apartada [STC 83/2002, ya citada]; publicación de fotografías de una mujer desnuda con ocasión del reportaje sobre un médico y su cuestionable conducta con sus pacientes, a las que fotografiaba desnudas [STS, 1 ${ }^{\mathrm{a}}, 17.6 .2004$ (Ar. 3628; MP: Rafael Ruiz de la Cuesta Cascajares)]; emisión de imágenes por parte de TVE de una menor víctima de malos tratos, persona que por el hecho de ser menor, nos dice el Tribunal, merece una especial protección [STS, 1a , 7.7.2004 (Ar. 5273; MP: Antonio Romero Lorenzo)]; publicación de las imágenes de una modelo en un reportaje sobre la prostitución de lujo [STS, 1 a 18.10 .2004 (Ar. 5907; MP: José Almagro Nosete)].

En todo caso si hay consentimiento se permite que se acepte la publicación por parte de la persona (art.2.2 LO 1/1982), especialmente si se trata de adultos [STS, ${ }^{\text {a }}$, 20.4.2001 (Ar. 5284; MP: José de Asís Garrote)], pues el consentimiento es una de las causas que eliminan la ilicitud en la intromisión .

Si se trata de menores, se suple su capacidad y se admite la posibilidad de que den su consentimiento, de acuerdo con lo previsto en la legislación - art. 3.1 de la LO 1/1982 - pero siempre que no se infrinjan los derechos de los menores previstos en el art. 4 de la LO 1/1996 de 15 de Enero, de Protección Jurídica del Menor, de modificación parcial del Código Civil y de la Ley de Enjuiciamiento Civil.

En realidad la LO de 1996 modifica la de 1982: en principio se considera siempre ilegítima la utilización de la imagen del menor- incluso aunque conste el consentimiento, la asistencia del fiscal, etc.,-- salvo que la información sea de interés público y no afecte al circulo íntimo del menor, tal como lo interpreta la jurisprudencia [SSTS, 1 a , 19.7.2000 (Ar. 6753; MP: Antonio Gullón Ballesteros) y 26.3.2003 (Ar. 2596; MP: Xavier O'Callaghan Muñoz)]. 
El segundo caso legitimador de la intromisión en la imagen es naturalmente el interés público de lo emitido; de acuerdo con el TC y el TS, a la hora de confrontación entre la libertad de información y la intimidad y la propia imagen, es elemento decisivo la relevancia pública del hecho divulgado, en cuyo conocimiento está interesada por motivos legítimos la opinión pública.

Y la opinión pública puede estar interesada legítimamente en temas muy importantes y a veces en temas aparentemente más nimios; como es el caso de la publicación de las fotografías de un conocido personaje comiendo en su celda (un bocadillo), que el Supremo consideró de interés público [STS, 1ª 8.7.2004 (Ar. 5112; MP: Ignacio Sierra Gil de la Cuesta)], pues, una vez admitido lo importante para la opinión pública de la divulgación del hecho de que un conocido financiero se encontraba en la cárcel y del lugar donde se hallaba, la foto venía a ser un complemento de la noticia de su prisión, teniendo en cuenta la repercusión social que tuvo el asunto en su momento

Pero, por supuesto, puede haber interés público en otros casos de consecuencias más graves, incluso relacionados con la muerte de una persona; así por ejemplo se considera el hecho de la publicación de la fotografía de un hombre ahogado en una playa, con indicación de su nombre y domicilio, ya que no se alimenta una curiosidad malsana, sino que se dan a conocer los peligros del mar y la actuación de un servicio público [STS, 1ª 28.5.2004 (Ar. 3977; MP: José Manuel Martínez-Pereda Rodríguez)].

Se trata, en suma, de la aplicación de la doctrina de ponderación entre intereses; sobre lo cual ya se había pronunciado la sentencia del TC [STC 72/2007, Sala Primera, 16.4.2007 (MP: Manuel Aragón Reyes)] que examina el caso de la publicación de la imagen de una agente de policía durante el desalojo de unas viviendas, y autoriza la intromisión por entender que entra dentro de las excepciones del art. 8.2 de la LO 1/1982 (carácter accesorio respecto de la información publicada y fotografía captada con motivo de un acto público) resumiendo la doctrina jurisprudencial sobre el derecho a la propia imagen cuando escribe que "(...) el derecho a la propia imagen no es absoluto o incondicionado, de suerte que existen circunstancias que pueden determinar que la regla general conforme a la cual es titular de este derecho a quien $\mathrm{m}$ en principio corresponde decidir si permite o no la captación por un tercero, ceda a favor de otros derechos o intereses constitucionalmente legítimos, lo que ocurrirá en los casos en los que exista un interés público en la captación o difusión de la imagen, y este interés público se considere constitucionalmente prevalente al interés de la persona en evitar la captación o difusión de su imagen. Por ello, cuando el derecho a la propia imagen entre en colisión con otros bienes o derechos constitucionalmente protegidos, particularmente las libertades de expresión e información (art. 20.1.a y d CE) deberán ponderarse los diferentes intereses $\mathrm{s}$ enfrentados $\mathrm{y}$, atendiendo a las circunstancias concretas de cada caso, decidir qué interés merece mayor protección (...)" (FJ $\left.5^{\circ}\right)$.

Es la idea, ya expresada por el TC en numerosas ocasiones, de que no hay derechos absolutos, y cuando colisionan derechos o intereses legítimos - y fundamentales, como en este caso - los tribunales han de decidir cual prevalece, siendo el concepto de interés público el que decidirá si predomina el derecho a la propia imagen o no, si bien la posición básica para la resolución de la colisión entre derechos debe ser la prevalencia (no jerárquica) que sobre los derechos de la personalidad ostenta el derecho a la libertad de información, aplicable si se da el requisito de que los hechos 
publicados sean de interés general o tengan trascendencia pública, con lo cual doy por concluida esta ponencia que, por supuesto, someto a cualquier otra opinión mejor fundamentada. 